\title{
JPEB
}

Jurnal Penelitian Ekonomi dan Bisnis, 5 (1), 2020, Hal: 16 - 26

http://www.jpeb.dinus.ac.id

\section{FAKTOR INTERNAL DAN EKSTERNAL SEBAGAI DETERMINAN PENINGKATAN PENYALURAN KREDIT BANK UMUM DI INDONESIA}

\author{
Ririh Dian Pratiwi ${ }^{1 *}$ dan Agung Prajanto ${ }^{2}$ \\ 1,2Program Studi Akuntansi, Fakultas Ekonomi dan Bisnis, Universitas Dian Nuswantoro \\ Jalan Nakula I No. 5-11 Semarang, Indonesia \\ *Corresponding Email : ririh.dian.pratiwi@dsn.dinus.ac.id
}

Diterima: Oktober 2019; Direvisi: Januari 2020; Dipublikasikan: Maret 2020

\begin{abstract}
This study aims to examine whether CAR, DPK, ROA, BIRate and Economic Growth affect the increase in lending to commercial banks in Indonesia. The population used is conventional commercial banks located in Indonesia and registered with OJK. Samples were obtained by purposive sampling method, with criteria (1) Conventional Commercial Banks in Indonesia which are found in the OJK in 2015-2018, (2) Publishes its financial statements, (3) Banks of all shares owned by Indonesian citizens, (4) Banks that experience credit score increases every Quarter of 2015-2018. The data analysis method used is quantitative statistics. The analysis conducted is multiple linear regression analysis. In addition to descriptive statistical testing, in multiple linear regression contains several tests, namely the classical assumption test, testing the regression model using the Statistical F-test, and testing the hypothesis using the Statistical t-test. The results obtained are that CAR and DPK do not affect the increase in lending. While the ROA, BIRate and Economic Growth variables proved to have an effect on the increase in lending to commercial banks in Indonesia in 2015-2018.
\end{abstract}

Keywords: Internal Factors; External Factors; Credit

\begin{abstract}
ABSTRAK
Penelitian ini bertujuan untuk menguji apakah CAR, DPK, ROA, BIRate dan Pertumbuhan Ekonomi berpengaruh terhadap Peningkatan Penyaluran Kredit pada Bank Umum di Indonesia. Populasi yang digunakan adalah Bank Umum Konvensional yang terdapat di Indonesia dan terdaftar pada OJK. Sampel diperoleh dengan metode purposive sampling, dengan kriteria (1) Bank Umum Konvensional di Indonesia yang terdapat di OJK tahun 2015-2018, (2) Mempublikasikan laporan keuangannya, (3) Bank seluruh sahamnya dimiliki Warga Negara Indonesia, (4) Bank yang mengalami kenaikan nilai kredit setiap Triwulan tahun 2015-2018. Metode analisis data yang digunakan adalah statistik kuantitatif. Analisis yang dilakukan adalah analisis regresi linier berganda. Selain pengujian statistik deskriptif, dalam regresi linier berganda memuat beberapa pengujian yaitu uji asumsi klasik, pengujian model regresi dengan menggunakan uji Statistik F, serta pengujian hipotesis dengan menggunakan uji Statistik t. Hasil penelitian yang diperoleh adalah CAR dan DPK tidak berpengaruh terhadap peningkatan penyaluran kredit. Sedangkan variabel ROA, BI Rate dan Pertumbuhan Ekonomi terbukti berpengaruh terhadap peningkatan penyaluran kredit pada Bank Umum di Indonesia tahun 2015-2018.
\end{abstract}

Kata Kunci: Faktor Internal ; Faktor Eksternal; Kredit 


\section{PENDAHULUAN}

Sistem keuangan sangatlah berperan penting dalam perekonomian di Indonesia. Dalam system perekonomian, sistem keuangan berfungsi menyalurkan dana dari pihak yang berlebih kepada pihak yang kekurangan. Perbankan merupakan salah satu bagian dari lembaga keuangan yang ikut serta menjadi bagian dalamsistem keuangan. Berdasarkan UU RI No.10 Tahun 1998 mengenai perbankan, diesebutkan bahwa bank merupakan badan usaha yang menghimpun dana dari masyarakat dan menyalurkan kepada masyarakat melalui kredit dan atau bentuk lainnya dalam rangka memajukan taraf hidup masyarakat. Saat ini, peran perbankan dalam mendukung stabilitas sistem keuangan masih sangat signifikan. Masyarakat masih sangat antusias dalam menyimpan dana ataupun berinvestasi dalam bentuk tabungan, giro atau deposito (Otoritas Jasa Keuangan, 2016).

Perbankan dapat berpartisipasi dalam mengatasi kesulitan ekonomi Negara, dengan berfungsi sebagai tempat berinvestasi maupun tempat penyaluran kredit. Dengan kegiatan penyaluran kredit yang dilakukan tersebut diharapkan mampu mendukung terciptanya lapangan kerja, membantu pemenuhan kebutuhan pokok, mengendalikan laju inflasi, serta dapat mendukung dunia usaha dan aktivitas ekspor-impor (Fahmi, 2014).

\begin{tabular}{cccc}
\multirow{2}{*}{ Tabel 1. Penyaluran Kredit Bank Umum, BPR dan Bank Syariah } \\
\multirow{2}{*}{ Tahun } & \multicolumn{3}{c}{ Rata-rata Kredit (Milyar Rp) } \\
\cline { 2 - 4 } & Bank Umum & \multicolumn{1}{c}{ BPR } & Bank Umum Syariah \\
\hline 2015 & 5.952 .279 & 98.604 & 153.968 \\
2016 & 6.570 .903 & 109.389 & 177.482 \\
2017 & 7.177 .549 & 121.296 & 189.789 \\
2018 & 7.729 .341 & 130.724 & 202.298 \\
\hline
\end{tabular}

Tabel 1 menyajikan data penyaluran kredit seluruh bank. Dari data tersebut dapat diartikan bahwa kebutuhan kredit terus meningkat. Menurut Kholisudin (2012) keterbatasan uang dalam masyarakat akan mendorong dalam melakukan kredit pada bank guna memperlancar kegiatan ekonomi mereka.

Pemberian kredit oleh bank kepada masyarakat dapat digolongkan menjadi tiga bagian, yaitu kredit konsumsi, multiguna dan modal kerja. Bank umum (konvensional) menyalurkan kredit bersumber dari asset yang dimiliki. Menurut Firdaus dan Ariyanti (2011) dalam kondisi ekonomi normal, capaian kredit sebesar 70\% hingga 90\% dari besarnya asset bank. Mengingat pencapaian tersebut dapat disimpulkan bahwa bagi perbankan, aktivitas kredit merupakan aktivitas yang dapat menjadi tumpuan utama menghasilkan pendapatan berupa bunga kredit. Dari aktivitas kredit yang berjalan lancar, bunga kredit yang dapat dicapai adalah pada tingkat $70 \%$ hingga $90 \%$ dari keseluruhan pendapatan bank. Namun, apabila kita melihat pada peraturan perbankan, yaitu ketentuan yang dikeluarkan Bank Indonesia mengenai rasio kecukupan modal (CAR), dapat mempengaruhi penyaluran jumlah kredit suatu oleh bank. Sedangkan menurut beberapa penelitian terdahulu, beberapa factor dapat mempengaruhi jumlah penyaluran kredit perbankan. Murdiyanto (2012), dalam penelitiannya menemukan bahwa CAR berpengaruh negatif terhadap kredit yang disalurkan. Sedangkan Satria dan Subegti (2010) menemukan hasil CAR berpengaruh positif pada kredit. Berbeda pula dengan penelitian Devi (2016), Setyawan (2016), serta Pratiwi dan Hindasah (2014) yang hasilnya adalah CAR tidak memiliki pengaruh terhadap penyaluran kredit.

Selain rasio kecukupan modal, dana yang diperoleh dari pihak ketiga (DPK) juga mempengaruhi jumlah penyaluran kredit. DPK yaitu dana yang berbentuk simpanan masyarakat. Hasil penelitian Pratama (2016) serta Pratiwi dan Hindasah (2014) menemukan bahwa DPK memiliki pengaruh positif terhadap penyaluran kredit. 
Sedangkan Satria dan Subegti (2010) dalam penelitiannya menemukan DPK tidak memiliki pengaruh pada kredit.

Penyaluran kredit tidak terlepas dari upaya dalam mengukur kemampuan manajemen bank. Dalam kaitannya dengan pengukuran kemampuan manajemen bank, ROA dapat digunakan dalam pengukuran perolehan keuntungan secara keseluruhan. Devi (2016) serta Satria dan Subegti (2010) menemukan hasil penelitian bahwa ROA berpengaruh positif pada penyaluran kredit. Sedangkan Setyawan (2016) serta Pratiwi dan Hindasah (2014) menemukan bahwa ROA tidak berpengaruh pada penyaluran kredit. Berbeda dengan penelitian Prihartini dan Dana (2018) yang menemukan ROA memiliki pengaruh negatif pada penyaluran kredit usaha rakyat.

Jumlah kredit yang disalurkan biasanya juga akan terpengaruh oleh perubahan suku bunga. Dampaknya adalah, ketika terjadi perubahan dalam jumlah kredit, maka selanjutnya akan mempengaruhi pendapatan bank. Menurut Fahmi (2014), keputusan manajerial yang bersifat jangka panjang maupun jangka pendek juga akan terpengaruh oleh nai atau turunnya suku bunga. Menurut hasil penelitian Devi (2016) serta Haryati (2009), ditemukan adanya pengaruh negatif antara BI Rate terhadap pertumbuhan kredit. Murdiyanto (2012) menemukan hasil bahwa terdapat pengaruh positif antara BI rate terhadap penyaluran kredit. Sedangkan Setyawan (2016) dan Pratama (2010) menemukan hasil bahwa BI rate tidak berpengaruh pada penyaluran kredit.

Dilihat dari faktor lain, ketidakstabilan keadaan ekonomi juga akan mempengaruhi pengambilan keputusan pemberian kredit. Penelitian Yustini (2015) menemukan bahwa pertumbuhan ekonomi berpengaruh positif pada penyaluran kredit. Hal tersebut berbeda dengan hasil penelitian Setyawan (2016) dimana tidak terdapat pengaruh pertumbuhan ekonomi pada pertumbuhan kredit.

Faktor yang dapat mempengaruhi peningkatan penyaluran kredit telah dijelaskan pada uraian di atas, didukung oleh berbagai hasil penelitian. Berdasarkan uraian tersebut maka tujuan dilakukannya penelitian ini yaitu mengetahui apakah CAR, DPK, ROA, BI Rate dan Pertumbuhan Ekonomi berpengaruh terhadap Peningkatan Penyaluran Kredit Bank Umum yang ada di Indonesia periode 2015-2018.

\section{TINJAUAN PUSTAKA Bank}

Undang-Undang Nomor 10 tahun 1998 mendefinisikan bank adalah lembaga perantara keuangan yang bertugas menghimpun dana yang berasal dari masyarakat berbentuk tabungan, deposito dan giro, serta menyalurkannya pada masyarakat melalui kredit serta bentuk lainnya (Otoritas Jasa Keuangan, 2016). Selain melaksanakan aktifitas penghimpunan dan penyaluran dana, bank melakukan aktifitas pelayanan jasa pengiriman uang, pembayaran, penitipan barang berharga, dan lain-lain. Semua aktifitas tersebut merupakan sumber pendapatan bagi perbankan. Biasanya, sumber pendapatan terbesar bank umumnya adalah berasal dari selisih bunga kredit dan bunga DPK.

Fungsi utama yang harus dimiliki bank adalah agen kepercayaan, agen pembangunan, dan agen pelayanan. Dalam metode menentukan harga, terdapat dua jenis bank, yang pertama bank yang berprinsip konvesional dan yang kedua bank yang berdasarkan prinsip syariah. Adapun berikut adalah gambar mengenai fungsi Bank (Otoritas Jasa Keuangan, 2016): 


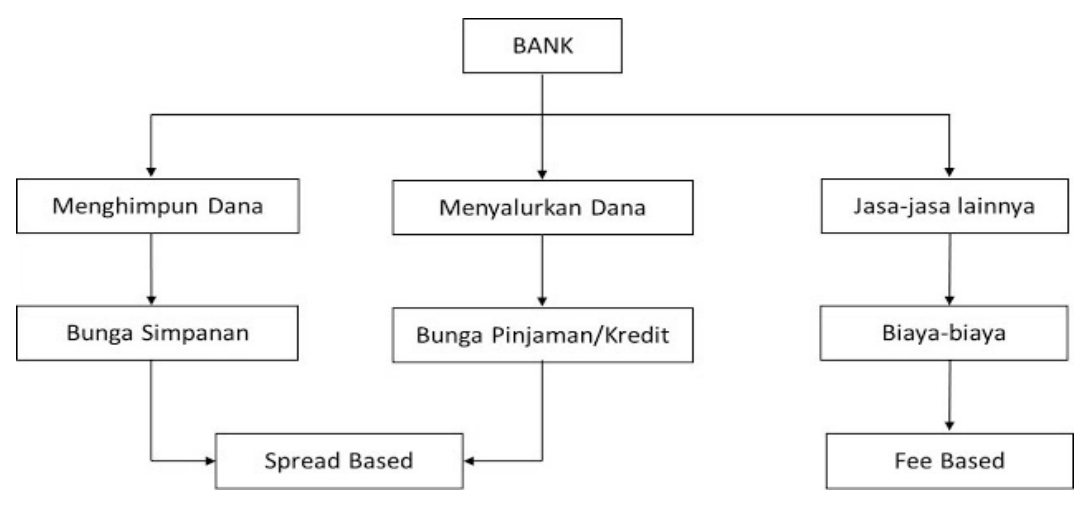

Gambar 1. Fungsi Bank

\section{Kredit}

Kredit merupakan produk pinjaman yang diselenggarakan oleh perbankan. Produk pinjaman yang dikelola perbankan terdiri dari beberapa jenis dan memiliki tujuan yang berbeda berdasarkan motif dari debitur. Terdapat tiga macam kredit, yaitu kredit usaha/modal kerja, kredit konsumsi dan kredit multiguna. Sedangkan menurut Kasmir (2017) dalam aktifitas penyaluran kredit, perbankan memiliki beberapa jenis kredit yang dikategorikan sesuai dengan kegunaan, kebutuhan, jangka waktu, sektor, serta pertimbangan lainnya. Dalam penyaluran kredit, terdapat beberapa prinsip yang harus dijalankan dalam pemutusan kredit, yaitu sebagai berikut:

1. Four-Eye Principle

2. Prisip One Obligor

3. Prinsip Konsolidasi Ekposur

4. Kepatuhan terhadap regulasi

5. Memenuhi karakteristik Analisis Kredit

6. Pemutusan kredit menggunakan data yang valid dan akurat

7. Up to date dan disclosure information

8. Bottom-up Approach

9. Pemantauan Kredit

\section{Capital Adequacy Ratio (CAR)}

CAR merupakan pengukuran mengenai kesanggupan bank dalam menutup penurunan aktiva akibat kerugian karena aktiva yang berisiko. Apabila penyaluran kredit oleh bank semakin besar, nilai ATMR akan ikut meningkat, sehingga nilai CAR akan menurun. Dalam pengambilan keputusan, apabila bank memutuskan akan melakukan perluasana atau peningkatan jumlah kredit yang diberikan, maka harus mempertimbangkan jumlah kepemilikan ekuitas saat itu. Terbatasnya nilai CAR yang dimiliki, apabila sudah mendekati ketentuan nilai minimal, keputusan perluasan kredit harus diiukuti dengan penambahan modal. Ketika bank tidak mengimbangi jumlah modal, dampaknya adalah terjadinya penurunan CAR dan akan tidak memenuhi ketentuan nilai minimum yaitu $8 \%$.

\section{Dana Pihak Ketiga (DPK)}

DPK merupakan dana yang bersumber dari masyrakat. DPK merupakan sumber dana utama yang dimiliki oleh bank. DPK terdiri dari beberapa jenis, antara lain giro, tabungan, deposito. Biasanya, jumalah DPK dapat mencai $80 \%$ sampai $90 \%$ dari total dana milik bank. Ketika suatu bank dapat menghimpun DPK yang besar, maka bank juga akan melakukan penyaluran kredit dalam jumlah besar. Sebaliknya, ketika DPK yang dihimpun hanya sedikit, tentu akan mempengaruhi likuiditas perbankan, yang berdampak pada menurunnya nilai penyaluran kredit. 
Ririh Dian Pratiwi dan Agung Prajanto : Faktor Internal Dan Eksternal Sebagai Determinan Peningkatan Penyaluran Kredit Bank Umum Di Indonesia

\section{Return On Assets (ROA)}

ROA adalah kemampuan bank dalam memperoleh dari penggunaan asset. Tingginya laba suatu bank, mengindikasikan kinerja bank tersebut, sehingga akan menumbuhkan kepercayaan masyarakat dan akan menguntungkan pihak perbankan. Dendawijaya (2009) menyatakan, semakin tinggi nilai ROA suatu bank akan menghasilkan tingkat keuntungan bank dari penggunaan asset yang dimiliki.

\section{Suku Bunga Bank Indonesia}

Pelaksanaan fungsi bank sebagai sarana intermediasi selalu terkait dengan suku bunga. Menurut Kurniawati (2016), suku bunga adalah suku bunga yang dijadikan pedoman yang menggambarkan kebijakan keuangan yang ditentukan oleh Bank Indonesia, serta secara langsung diumumkan kepada masyarakat. Suku bunga dapat mempengaruhi keputusan ekonomi masyarakat dalam aktifitas konsumsi, pembelian rumah, pembelian obigasi, ataupun menabung. Peningkatan suku bunga akan mengakibatkan masyarakat lebih suka untuk menyimpan uangnya di bank. Sebaliknya, ketika suku bunya turun, maka masyarakat akan tertarik untuk melakukan pengambilan atas simpanan mereka yang ada di bank dan memililih untuk menginvestasikan pada alternativ investasi yang lebih menarik. Peningkatan suku bunga akan mendorong bank untuk meningkatkan bunga simpanan agar simpanan masyarakat meningkat. Hal tersebut seiring dengan fungsi BI rate yaitu menjaga inflasi melalui proses penyesuian dengan memperketat jumlah peredaran uang apabila terjadi kenaikan harga yang tinggi.

\section{Pertumbuhan Ekonomi}

Pertumbuhan ekonomi yaitu proses meningkatnya kegiatan ekonomi dalam masyarakat yang memiliki dampak pada naiknya jumlah produksi barang/jasa dan mengakibatkan peningkatan pada pendapatan nasional. Pertumbuhan ekonomi juga terkait dengan konsep yang berprospek jangka panjang. Proses pertumbuhan ekonomi harus dapat menciptakan kekuatan dalam kelanjutan pertumbuhan periode-periode yang akan datang. Hal inilah yang disebut bahwa pertumbunhan ekonomi adalah suatu proses yang memiliki sifat self-generating.

\section{METODE PENELITIAN}

Penelitian ini menggunakan variabel terikat dan variabel bebas. Menurut Ghozali (2015) variabel terikat didefinisikan sebagi variabel yang dipengaruhi oleh variabel yang lain. Variabel bebas yaitu variabel yang mampu mempengaruhi variabel terikat. Variabel terikat yang digunakan adalah penyaluran kredit. Variabel bebas yang digunakan adalah Capital Adequacy Ratio (CAR), Pertumbuhan Dana Pihak Ketiga (DPK), Return On Assets (ROA), Suku Bunga Bank Indonesia (BI rate) dan Pertumbuhan Ekonomi. Adapun pengukuran variabel dijelaskan pada table berikut ini :

\section{Tabel 2. Pengukuran Variabel}

\begin{tabular}{cccc}
\hline No & Variabel & \multicolumn{1}{c}{ Pengukur } & Sumber Data \\
\hline 1 & CAR & $\begin{array}{l}\text { Pada periode triwulan yang dinyatakan } \\
\text { dalam persentase. }\end{array}$ & OJK \\
& & $C A R=\frac{\text { Modal Bank }}{\text { ATMR }} \times 100 \%$ &
\end{tabular}

$2 \quad$ DPK

Pada periode triwulan yang dinyatakan dalam

OJK

persentase.

$$
D P K=\frac{D P K_{t}-D P K_{t-1}}{D P K_{t-1}} \times 100 \%
$$




\begin{tabular}{|c|c|c|c|}
\hline 3 & ROA & $\begin{array}{l}\text { Pada peridoe triwulan (dinyatakan } \\
\text { dalam persentase) } \\
\text { ROA }=\frac{\text { Laba Bersih }}{\text { Total Aset }} \times 100 \%\end{array}$ & OJK \\
\hline 4 & $\mathrm{BI}$ rate & $\begin{array}{l}\text { Tingkat suku bunga pada periode triwulan } \\
\text { yang dinyatakan dalam persentase. }\end{array}$ & BI \\
\hline 5 & $\begin{array}{l}\text { Pertumbuhan } \\
\text { Ekonomi }\end{array}$ & $\begin{array}{l}\text { Pertumbuhan Ekonomi pada periode triwulan } \\
\text { dinyatakan dalam persentase yang diukur dari } \\
\text { kenaikan PDB atas dasar } \\
\text { harga konstan. }\end{array}$ & BPS \\
\hline \multirow[t]{2}{*}{6} & $\begin{array}{l}\text { Peningkatan } \\
\text { Kredit }\end{array}$ & $\begin{array}{l}\text { Perhitungan selisih kredit Bank Umum pada } \\
\text { periode triwulan (dinyatakan dalam } \\
\text { persentase) }\end{array}$ & OJK \\
\hline & & Kredit $=\frac{\text { Kredit }_{t}-\text { Kredit }_{t-1}}{\text { Kredit }_{t-1}} \times 100 \%$ & \\
\hline
\end{tabular}

Populasi yang digunakan adalah Bank Umum di Indonesia dan terdaftar pada OJK tahun 2015-2018. Sampel dengan purposive sampling dengan empat (4) kriteria yaitu (1) Bank Umum di Indonesia yang terdapat di OJK tahun 2015-2018, (2) Mempublikasikan laporan keuangannya, (3) Bank yang seluruh sahamnya dimiliki WNI, (4) Bank yang mengalami kenaikan Triwulan dari 2015 sampai dengan 2018.

Statistik kuantitatif digunakan sebagai metode analisis data. Selain pengujian statistik deskriptif, dalam regresi linier berganda memuat beberapa pengujian yaitu uji asumsi klasik, pengujian model regresi dengan menggunakan uji Statistik F, serta pengujian hipotesis dengan menggunakan uji Statistik t. Penelitian ini menggunakan persamaan regresi sebagai berikut:

Dimana:

$$
\mathrm{Y}=\alpha+\beta 1 \mathrm{CAR}+\beta 2 \mathrm{DPK}+\beta 3 \mathrm{ROA}+\beta 4 \mathrm{BIrate}+\beta 5 \mathrm{PE}+\mathrm{e}
$$

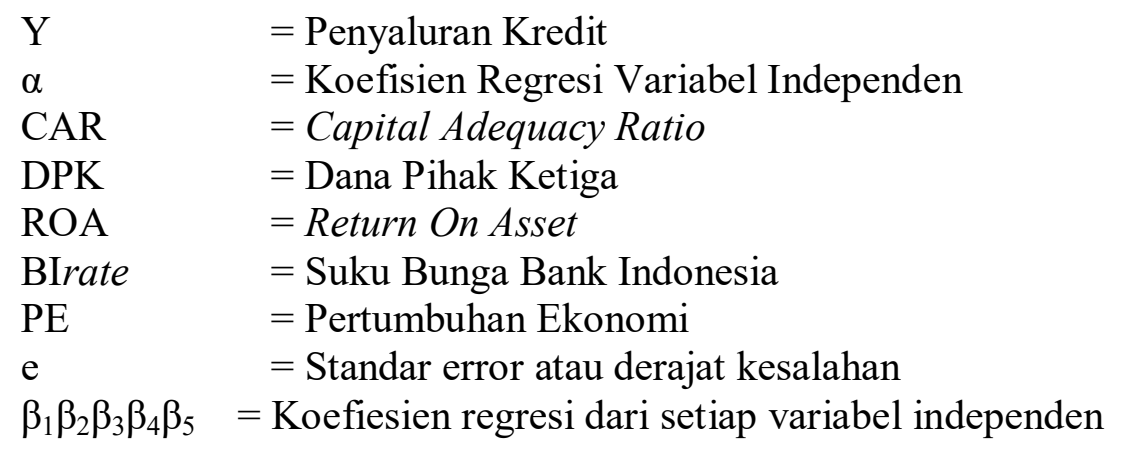

\section{HASIL DAN PEMBAHASAN \\ Deskripsi Data}

Berdasarkan kriteria diperoleh sampel sebanyak 42 bank yang diamati selama empat tahun. Sehingga obervasi yang diperoleh sebesar 168 bank. Namun, data yang telah memenuhi pengujian dan asumsi klasik serta dapat dilanjutkan pada pengujian selanjutnya adalah sebanyak 160 observasi. Adapun deskripsi statistik data dtunjukkan pada tabel berikut: 
Ririh Dian Pratiwi dan Agung Prajanto : Faktor Internal Dan Eksternal Sebagai Determinan Peningkatan Penyaluran Kredit Bank Umum Di Indonesia

Tabel 3. Statistik Deskriptif

\begin{tabular}{lcrrrr}
\hline & N & Minimum & Maximum & Mean & $\begin{array}{c}\text { Std. } \\
\text { Deviation }\end{array}$ \\
\hline ROA & 160 & .03 & 5.57 & 2.6516 & 1.22062 \\
CAR & 160 & 1.19 & 58.60 & 20.1825 & 6.11665 \\
DPK & 160 & .04 & 85.00 & 9.5234 & 2.59690 \\
BI_RATE & 160 & 4.75 & 7.67 & 7.0354 & .88465 \\
PERT_EKO & 160 & .18 & 4.02 & 2.2278 & 1.21601 \\
PENYALURAN & 160 & .05 & 15.78 & 4.7965 & 3.19624 \\
\hline Valid N & 160 & & & & \\
(listwise) & & & & & \\
\hline
\end{tabular}

Pada tabel 3 terlihat data yang digunakan dalam penelitian berjumlah 160 observasi. Semua variabel memiliki sebaran data yang baik, hal tersebut dapat terlihat dari nilai Mean yang lebih besar dari deviasi standarnya.

\section{Uji Asumsi Klasik}

Uji asumsi klasik dalam penelitian sebanyak empat pengujian, yaitu uji normalitas, multikolinearitas, heterokedasisitas dan uji autokorelasi. Adapun pengujian-pengujian tersebut dijelaskan dalam uraian ini:

Tabel 4. Pengujian Normalitas Pertama

\begin{tabular}{lr}
\hline & Unstandardized Residual \\
\hline $\mathbf{N}$ & 163 \\
Test Statistic & .076 \\
Asymp. Sig. (2-tailed) & $.022^{\mathrm{c}}$ \\
c. Lilliefors Significance Correction. & \\
\hline
\end{tabular}

Tabel 5. Pengujian Normalitas Kedua

\begin{tabular}{lr}
\hline & Unstandardized Residual \\
\hline $\mathbf{N}$ & 160 \\
Test Statistic & .051 \\
& \\
Asymp. Sig. (2-tailed) & $.200^{\mathrm{c}, \mathrm{d}}$ \\
\hline
\end{tabular}

Pada tabel 4 terlihat nilai Asymp. Sig sebesar 0,02. Nilai tersebut lebih kecil dari 0,05, maka disimpulkan bahwa data penelitian tidak memenuhi asumsi normalitas. Untuk itu dilakukan metode outlier untuk mengidentifikasi data-data yang terindikasi ekstrim dan harus dikeluarkan dari data penelitian. Setelah dilakukan outlier, terdapat 8 data ekstrim yang dikeluarkan dari sampel penelitian. Adapun hasil data pengujian normalitas yang kedua ditunjukkan pada tabel 5 . Tabel 5 menunjukkan nilai Asymp. 0,200. Nilai tersebut lebih besar dari 0,05, sehingga data dalam penelitian terdistribusi normal atau memenuhi asumsi normalitas

Pengujian Multikolinearitas dapat dilihat dari tabel Coefficient. Dari tabel tersebut terlihat bahwa Tolerance dari semua variabel bernilai lebih besar dari 0,1 dan VIF dari semua variabel bernilai lebih kecil dari 10. Oleh karenanya, kesimpulan yang dapat diambil adalah penelitilian ini terbebas dari gejala multikolinearitas. 
Tabel 6. Uji Multikolinearitas

\begin{tabular}{llcc}
\hline \multirow{2}{*}{\multicolumn{2}{c}{ Model }} & \multicolumn{2}{c}{ Collinearity Statistics } \\
\cline { 2 - 3 } & Tolerance & VIF \\
\hline ROA & & \\
& CAR & .849 & 1.177 \\
& DPK & .845 & 1.183 \\
& BI_RATE & .834 & 1.199 \\
& PERT_EKO & .947 & 1.056 \\
& .911 & 1.097 \\
\hline
\end{tabular}

a. Dependent Variable: PENYALURAN

Pengujian heterokedastisitas dilakukan dengan meregresikan semua variabel bebas dengan nilai absolut residual dari model tersebut. Dari pengujian yang dilakukan, semua variabel bebas memiliki probabilitas signifikansi lebih besar dari 0,05. Oleh karena itu dapat diartikan bahwa dalam penelitian ini, model terbenas dari gejala heterokedastisitas.

Tabel 7. Uji Heterokedastisitas

\begin{tabular}{lll}
\hline & Model & Sig. \\
\hline 1 & (Constant) & .052 \\
& ROA & .210 \\
CAR & .055 \\
& DPK & .059 \\
& BI_RATE & .495 \\
& PERT_EKO & .349 \\
\hline
\end{tabular}

Pengujian asumsi klasik yang terakhir adalah uji autokorelasi. Uji autokorelasi dilakukan dengan uji Durbin-Watson pada tabel berikut ini:

Tabel 8. Pengujian Autokorelasi

\begin{tabular}{cccccc}
\hline Model & $\mathbf{R}$ & $\begin{array}{c}\mathbf{R} \\
\text { Square }\end{array}$ & $\begin{array}{c}\text { Adjusted R } \\
\text { Square }\end{array}$ & $\begin{array}{c}\text { Std. Error of } \\
\text { the Estimate }\end{array}$ & $\begin{array}{c}\text { Durbin- } \\
\text { Watson }\end{array}$ \\
\hline $\mathbf{1}$ & $.445^{\mathrm{a}}$ & .198 & .172 & 2.90816 & 1.974 \\
\hline
\end{tabular}

Berdasarkan tabel terlihat nilai Durbin-Watson 1,974. Nilai dl yang diperoleh dengan $\mathrm{K}=5$ dan $n=160$ adalah 1,6776. Sedangkan nilai du yang diperoleh sebesar 1,8063 . Karena hasil perhitungan korelasi menunjukkan pada kondisi $\mathrm{du}<\mathrm{dw}<4$-du $(1,8063<1,974<2,1937)$, disimpulkan bahwa data pada penelitian ini bebas dari masalah autokorelasi.

\section{Pengujian Model (Uji Statistik F)}

Tabel 9. Uji Statistik F

\begin{tabular}{ccccccc}
\hline Model & $\begin{array}{c}\text { Sum of } \\
\text { Squares }\end{array}$ & df & $\begin{array}{c}\text { Mean } \\
\text { Square }\end{array}$ & F & Sig. \\
\hline 1 & Regression & 321.901 & 5 & 64.380 & 7.612 & $.000^{\mathrm{b}}$ \\
& Residual & 1302.439 & 154 & 8.457 & & \\
& Total & 1624.339 & 159 & & & \\
\hline
\end{tabular}

Berdasarkan tabel terlihat angka signifikasi 0,000 . Nilai tersebut lebih besar apabila dibandingkan dengan taraf nyata 0,05 . Oleh karena itu kesimpulan yang diperoleh adalah secara 
Ririh Dian Pratiwi dan Agung Prajanto : Faktor Internal Dan Eksternal Sebagai Determinan Peningkatan Penyaluran Kredit Bank Umum Di Indonesia

bersama-sama kelima variabel independen dalam penelitian ini, yaitu CAR, DPK, ROA, BIRate dan Pertumbuhan Ekonomi berpengaruh pada peningkatan penyaluran kredtt perbankan yang terdaftar di BEI.

\section{Uji Statistik t (Pengujian Hipotesis)}

Pengujian hipotesis dengan uji statistik t dapat dilihat dari tabel berikut ini:

Tabel 10. Pengujian Statistik t

\begin{tabular}{lcccccc}
\hline \multirow{2}{*}{ Model } & & \multicolumn{2}{c}{$\begin{array}{c}\text { Unstandardized } \\
\text { Coefficients }\end{array}$} & $\begin{array}{c}\text { Standardized } \\
\text { Coefficients }\end{array}$ & & \multirow{2}{*}{ Sig. } \\
\cline { 3 - 5 } & & B & $\begin{array}{c}\text { Std. } \\
\text { Error }\end{array}$ & Beta & & \\
\hline $\mathbf{1}$ & (Constant) & 1.007 & 2.185 & & .461 & .646 \\
& ROA & -.573 & .205 & -.219 & -2.794 & .006 \\
& CAR & -.064 & .041 & -.122 & -1.553 & .122 \\
& DPK & .026 & .020 & .101 & 1.282 & .202 \\
& BI_RATE & .642 & .268 & .178 & 2.398 & .018 \\
& PERT_EKO & .822 & .199 & .313 & 4.135 & .000 \\
\hline
\end{tabular}

Berdasarkan hasil pengujian pada tabel Coefficient, nilai signifikansi CAR 0,122. lebih besar dari 0,05. CAR tidak berpengaruh pada penyaluran kredit. Hasil penelitian menunjukkan kecukupan modal bank tidak berpengaruh pada naik atau turunnya penyaluran kredit. Rasio ini ditentukan standar minimalnya oleh Bank Indonesia, sehingga dimungkinkan, perbankan di Indonesia berupaya untuk memenuhi regulasi tersebut, namun tidak sejalan dengan perubahan jumlah kredit yang disalurkan kepada nasabah. Rata-rata semua perusahaan sampel memiliki nilai CAR jauh lebih besar dari nilai standar 8\%. Menurut data penelitian, nilai CAR memiliki rata-rata $20,18 \%$, dan hamper semua perbankan yang menjadi sampel memiliki nilai CAR tidak jauh dari nilai rata-rata CARnya. Namun apabila dilihat dari tingkat penyaluran kredit yang dilakukan, perbankan yang menjadi sampel memiliki rentang tingkat yang fluktuatif. Sehingga apabila dilihat dari sebaran data sampel, perusahaan dengan tingkat CAR yang sama terbukti memiliki tingkat penyaluran kredit yang bervariasi dan berbeda-beda. Hasil penelitian ini tidak sejalan dengan hasil penelitian Suryawati (2014) yang menemukan hasil bahwa kecukupan modal berpengaruh positif terhadap penyaluran kredit.

Berdasarkan hasil pengujian, diperoleh nilai signifikansi DPK sebesar 0,202 lebih besar dari 0,05. Disimpulkan bahwa hipotesis kedua ditolak. Bank seharusnya dapat mengoptimalkan menghimpun DPK untuk dapat disalurkan kembali kepada nasabah. Namun hasil dari penelitian ini menunjukkan bahwa DPK tidak berpengaruh pada penyaluran kredit. Pada penelitian, dapat dilihat bahwa data DPK dari perusahaan sampel cenderung fluktuatif dan beragam, namun tidak diiringi dengan nilai penyaluran kredit yang dilakukan. Sebagai contoh, bank yang memiliki DPK yang tinggi belum tentu memiliki tingkat penyaluran kredir yang tinggi, sebaliknya, pada bank yang memiliki DPK rendah, juga tidak selalu memiliki DPK yang rendah. Hasil penelitian ini tidak sesuai dengan hasil penelitian Suryawati (2014), Murdiyanto (2012), Yuda dan Meiranto (2010), Pratiwi dan Hindasah (2014), Setyawan (2016), dan Pratama (2010) yang menemukan bahwa DPK berpengaruh positif pada penyaluran kredit.

Berdasarkan hasil pengujian, pada tabel Coefficient diperoleh nilai signifikansi 0,006 yang lebih kecil dari 0.05 . Hipotesis ketiga diterima, menunjukkan ROA berpengaruh signifikan padapenyaluran kredit. ROA adalah rasio yang menggambarkan tingkat pengembalian dari penggunaan asset. Besar atau kecilnya ROA akan berpengaruh terhadap besarnya dana yang disalurkan kepada nasabah dalam bentuk kredit. Karena besarnya nilai ROA besar akan menunjukkan besarnya penghasilan bank yang dapat digulirkan kembali kepada nasabah dalam 
bentuk kredit. Hasil penelitian ini mendukung penelitian yang dihasilkan oleh Devi (2016) yang menyatakan bahwa ROA berpengaruh positif terhadap penyaluran kredit.

Nilai signifikansi suku bunga Bank Indonesia menunjukkan nilai 0,018. Nilai tersebut lebih kecil dari 0,05, sehingga dapat disimpulkan bahwa hipotesis keempat diterima. Suku bunga Bank Indonesia (BI rate) berpengaruh signifikan terhadap peningkatan penyaluran kredit perbankan di Indonesia. Naik atau turunnya suku Bunga BI akan berdampak pada naik atau turunnya suku bunga kredit. Tinggi atau rendahnya suku bunga kredit tentu saja akan dipertimbangkan oleh calon debitur dalam pengambilan keputusan kredit.

Berdasarkan hasil yang tertera pada tabel Coefficient dapat dilihat bahwa nilai probabilitas signifikasi sebesar 0,000. Nilai tersebut lebih kecil dari taraf nyata 0,05. Kesimpulan dari nilai tersebut yaitu bahwa hipotesis kelima yang menyatakan bahwa pertumbuhan ekonomi berpengaruh terhadap peningkatan penyaluran kredit, diterima. Kondisi perekonomian yang baik akan meningkatkan pertumbuhan ekonomi. Dengan kondisi perekonomian yang baik bank dan cenderung bertumbuh juga akan berdampak pada keputusan bank dalam menggulirkan kredit. Hal tersebut juga akan diterima masyarakat, karena dari sudut pandang masyarakat, perekonomian yang bertumbuh akan mendorong masyarakat untuk mengambil keputusan kredit, salah satunya adalah kerdit modal kerja. Apabila kondisi perekonomian sedang buruk, pihak perbankan juga akan mempertimbangkan dalam keputusan perguliran kredit kepada masyarakat. Hasil penelitian ini sejalan dengan hasil penelitian Yustini (2015) yang menyatakan bahwa karena terjadi kenaikan pada pertumbuhan ekonomi, tentu saja akan berdampak pada penghasilan masyarakat. Apabila penghasilan meningkat, tentu saja akan diikuti oleh pola konsumsi masyarakat yang akan mengakibatkan pada kenaikan output.

\section{SIMPULAN}

Simpulan dalam penelitian ini adalah dari kelima variabel independen, terdapat tiga variabel yang berpengaruh terhadap peningkatan penyaluran kredit, yaitu ROA, BI rate dan Pertumbuhan ekonomi. Sedangkan dua variabel lainnya yaitu CAR dan DPK terbukti tidak berpengaruh terhadap peningkatan penyaluran kredit pada perbankan di Indonesia yang terdaftar di BEI tahun 2015 sampai dengan tahun 2018. Keterbatasan dari penelitian ini adalah hasil pengujian koefisien determinasi yang tidak tinggi, sehingga menunjukkan hanya sebesar 17,2\% variasi dari variabel penyaluran kerdit dapat dijelaskan oleh kelima variabel independen yang dipakai dalam penelitian ini. Hasil dari penelitian ini dapat berkontribusi bagi pengembangan keilmuan dan dapat menjadi rujukan untuk penelitian selanjutnya.

Saran yang diajukan oleh peneliti untuk penelitian selanjutnya adalah, karena kemampuan kelima variabel independen yang digunakan dalam menggambarkan variasi variabel dependen dalam penelitian ini hanya $17,2 \%$, maka sebaiknya untuk penelitian selanjutnya dapat ditambah atau menggunakan variabel independen lainnya, seperti Non Performing Loan (NPL), Loan to Deposit Ratio (LDR), atau variabel lainnya.

\section{DAFTAR PUSTAKA}

Dendawijaya, L. 2009. Manajemen Perbankan edisi kedua. Bogor: Ghalia Indonesia.

Devi, H. P. 2016. Analisis Pengaruh CAMEL dan Suku Bunga SBI Terhadap Jumlah Penyaluran Kredit Pada Bank Umum Konvesional Go Public Di Indonesia Periode 2011-2014. ProBank, Jurnal Ekonomi dan Perbankan. 2 (2):19-27.

Fahmi, Irham. 2014. Manajemen Keuangan Perusahaan dan Pasar Modal. Jakarta: Mitra Wacana Media.

Firdaus, R., \& Ariyanti, M. 2011. Manajemen Perkreditan Bank Umum. Bandung : Alfabeta.

Ghozali, Imam. 2015. Aplikasi Analisis Multivariate Dengan Program IBM SPSS 21 Edisi 7. Semarang : Badan Penerbit Universitas Diponegoro 
Haryati, Sri. 2009. Pertumbuhan Kredit Perbankan Di Indonesia : Intermediasi dan Pengaruh Variabel Makro Ekonomi. Jurnal Keuangan dan Perbankan. 12 (2): 299-310.

Kasmir. 2014. Manajemen Perbankan. Jakarta: PT Raja Grafindo Persada. 2017. Analisis Laporan Keuangan edisi kesepuluh. Jakarta: PT. Raja Grafindo Persada.

Kholisudin, Akhmad. 2012. Determinan Permintaan Kredit Pada Bank Umum Di Jawa Tengah 2006-2010. Economics Development Analysis Journal. 1(1): 10-18.

Kurniawati, Risa. 2016. Analisis Faktor Yang Memengaruhi Kredit Yang Dikeluarkan Bank Umum Tahun 2011-2015. Skripsi. Yogyakarta: Universitas Negeri Yogyakarta.

Murdiyanto, Agus. 2012.. Faktor-Faktor Yang Berpengaruh dalam Penentuan Penyaluran Kredit Perbankan. Conference In Business Accounting and Management. 1(1) :61-75.

Pratama, B. A. 2010. Analisis Faktor-Faktor Yang Mempengaruhi Kebijakan Penyaluran Kredit Perbankan (Studi pada Bank Umum di Indonesia Periode Tahun 2005-2009). Jurnal Bisnis Strategi. 19 (2): 135-148.

Pratiwi, S., \& Hindasah, L. 2014. Pengaruh Dana Pihak Ketiga, Capital Adequacy Ratio, Return On Asset, Net Interest Margin dan Non Performing Loan Terhadap Penyaluran Kredit Bank Umum di Indonesia. Jurnal Manajemen \& Bisnis. 5(2): 192-208.

Prihartini, Suci \& Dana, I Made. 2018. Pengaruh CAR, NPL, Dan ROA Terhadap Penyaluran Kredit Usaha Rakyat. E-Jurnal Manajemen Unud. 7(3): 1168-1194

Satria, D., \& Subegti, R. B. 2010. "Determinasi Penyaluran Kredit Bank Umum Di Indonesia Periode 2006-2009". Jurnal Keuangan dan Perbankan.14(3): 415-424.

Setyawan, Onny. 2016. Pengaruh DPK, CAR, NPL, ROA, SBI Dan Pertumbuhan Ekonomi Terhadap Penyaluran Kredit Perbankan Pada Bank Umum Yang Terdaftar Di Bursa Efek Indonesia. KURS. 1(1): 125-139.

Suryawati, Ni Made Anik, dkk. 2014. Analisis Pengaruh Dana Pihak Ketiga (DPK), Capital Adequacy Ratio (CAR), Non Performing Loan (NPL), dan Loan to Deposit Ratio (LDR) Terhadap Jumlah Penyaluran Kredit (Studi Kasus Pada Lpd Desa Pakraman Pemaron Periode 2010-2013). E-Journal Bisma Universitas Pendidikan Ganesha. 2.

www.ojk.go.id

Yuda, I. M., \& Meiranto, W. 2010. Pengaruh Faktor Internal Bank Terhadap Jumlah Kredit Yang Disalurkan (Studi Empiris Pada Bank Yang Terdaftar Di Bursa Efek Indonesia). Jurnal Akuntansi \& Auditing. 7(1): 94-11

Yustini, Tien. 2015. Pengaruh Suku Bunga, Jumlah Perusahaan dan Pertumbuhan ekonomi Terhadap Penyaluran Kredit Modal Kerja Bagi UMKM di Sumatera Selatan. Jurnal Keuangan dan Perbankan. 19(3): 463-474. 